\title{
Measurement of saccharifying cellulase
}

\section{Douglas E Eveleigh*, Mary Mandels, Raymond Andreotti and Charles Roche}

\author{
Address: US Army Natick Development Center, Natick, Massachusetts 0760, USA \\ E-mail: Douglas E Eveleigh* - eveleigh@AESOP.rutgers.edu; Mary Mandels - not@valid.com; Raymond Andreotti - not@valid.com; \\ Charles Roche - not@valid.com \\ *Corresponding author
}

Published: 0 I September 2009

Biotechnology for Biofuels 2009, 2:21 doi: 10.1186/1754-6834-2-21
Received: 19 June 2009

Accepted: I September 2009

This article is available from: http://www.biotechnologyforbiofuels.com/content/2/l/2।

(c) 2009 Eveleigh et al; licensee BioMed Central Ltd.

This is an Open Access article distributed under the terms of the Creative Commons Attribution License (http://creativecommons.org/licenses/by/2.0), which permits unrestricted use, distribution, and reproduction in any medium, provided the original work is properly cited.

\begin{abstract}
This article sets forth a simple cellulase assay procedure. Cellulose is variable in nature, insoluble and resistant to enzymatic attack. As a result there have been a bevy of bewildering cellulase assays published that yielded irrational results. Certain protocols focused on the rapidity of the assay while ignoring that only the most readily susceptible cellulose regions were being hydrolyzed. Other assays simplified the system by using modified soluble substrates and yielded results that bore no relationship to the real world hydrolysis of insoluble cellulose. In this study Mandels, Andreotti and Roche utilized a common substrate, Whatman filter paper. Hydrolysis of a $50 \mathrm{mg}$ sample of the paper was followed to roughly $4 \%$ degradation, which circumvented the problems of attack of only the most susceptible zones. This common hydrolysis target range also resulted in some balance with regard to the interaction of the several cellulase components. The method was subsequently widely adopted.

Douglas E Eveleigh
\end{abstract}

\section{Introduction}

As we move from laboratory research by microbiologists and biochemists to pilot plant and development studies by chemical engineers and industrialists, it is necessary to look at cellulose saccharification in a quantitative and economic manner. A major cost factor will be the cellulase enzymes. The engineer wishes a simple welldefined unit of cellulase on which he can put a dollar value based on capital and operating costs of fermentation, and from which he can predict sugar output in his reactor. This would appear to be a simple and easily satisfied requirement, but it is not. A bewildering array of substrates, enzyme actions, units, and activities have been used (Table 1). Part of the confusion is due to the tendency of workers to develop their own assays, and then modify them. As Matti Linko said in Finland [2] 'A biochemist would sooner use his colleagues' tooth brush than his assay procedure'. But most of the confusion is inherent in the multiplicity of both substrate and enzyme and the necessity of predicting the $40 \%$ to $50 \%$ conversion of a concentrated cellulose slurry from a reasonably short assay based on limited conversion of a much smaller quantity of substrate.

Cellulose is deceptively simple chemically, a polymer consisting only of glucose linked only by $\beta 1,4$ bonds. But cellulose samples of different origin vary widely in chain length and the degree of interaction between the chains [3]. Furthermore, waste cellulose usually consists of only $40 \%$ to $60 \%$ cellulose with the balance consisting of hemicelluloses, lignins, and other materials. Many cellulase preparations also contain hemicellulases. If they are present, the hemicelluloses are rapidly hydrolyzed since they are much less recalcitrant to enzyme action than is cellulose. Amorphous cellulose is also rapidly hydrolyzed and then the rate of hydrolysis 
Table I: Cellulase Assays

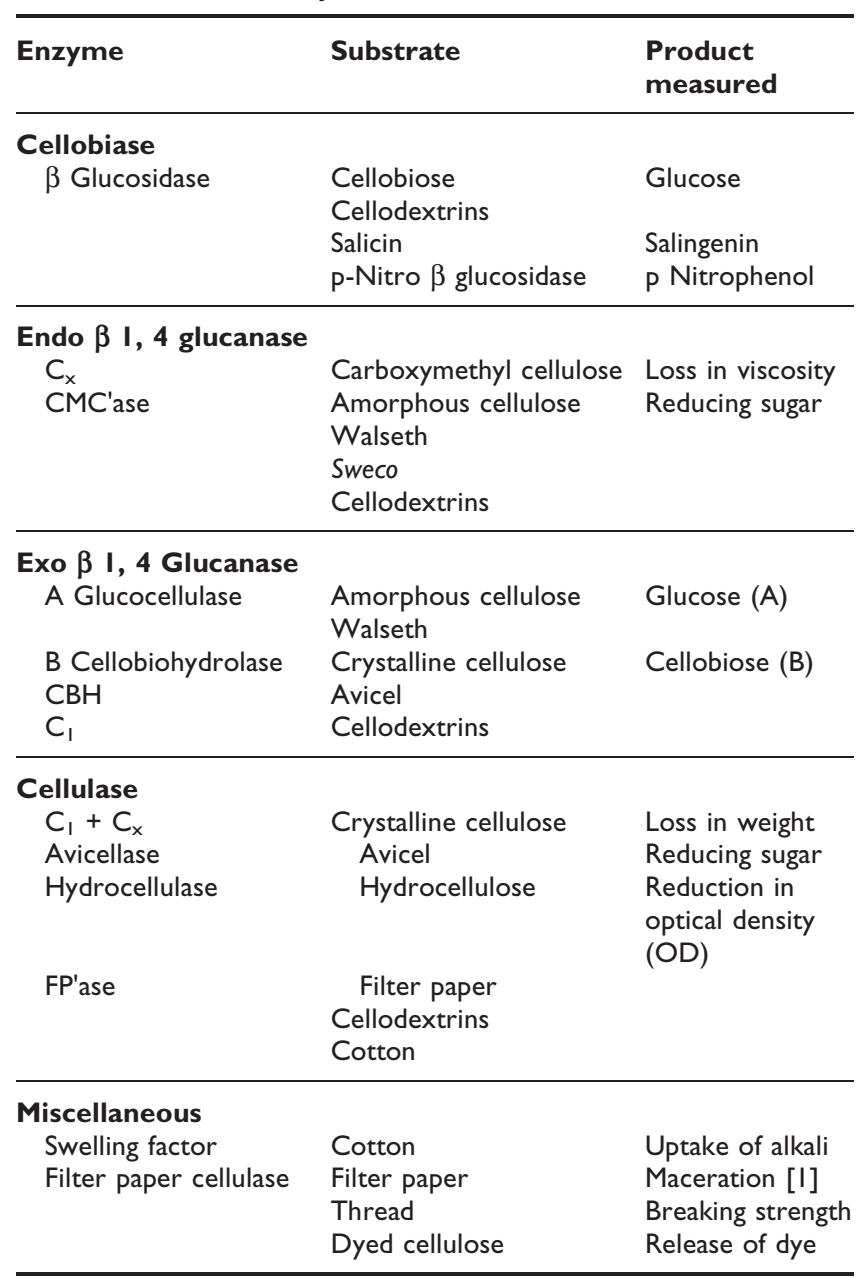

$\mathrm{CMC}=$ carboxymethyl cellulose; $\mathrm{FP}=$ filter paper.

decreases greatly as the increasingly crystalline portions of the cellulose are attacked (Figure 1).

Cellulase is a complex of enzymes containing chiefly endo and exo $\beta$ glucanases plus cellobiase. For complete hydrolysis of insoluble cellulose, synergistic action between the components is required. Since different cellulase preparations vary widely in the proportions of the different components, depending on source, growing conditions of the organism, and harvesting and handling procedures, the rate and extent of their hydrolysis of cellulose substrates also varies widely. Assay of purified components requires a variety of fairly complicated procedures that can be confusing to persons whose chief interest is in practical applications. In Finland (1975) the question arose 'What one substrate can be used to measure all the cellulase components?' Dr L G Petterson [4] opted for cellotetraose because it is acted on by all known members of the cellulase complex. Dr G Halliwell [5] decided on cotton because only a complete cellulase

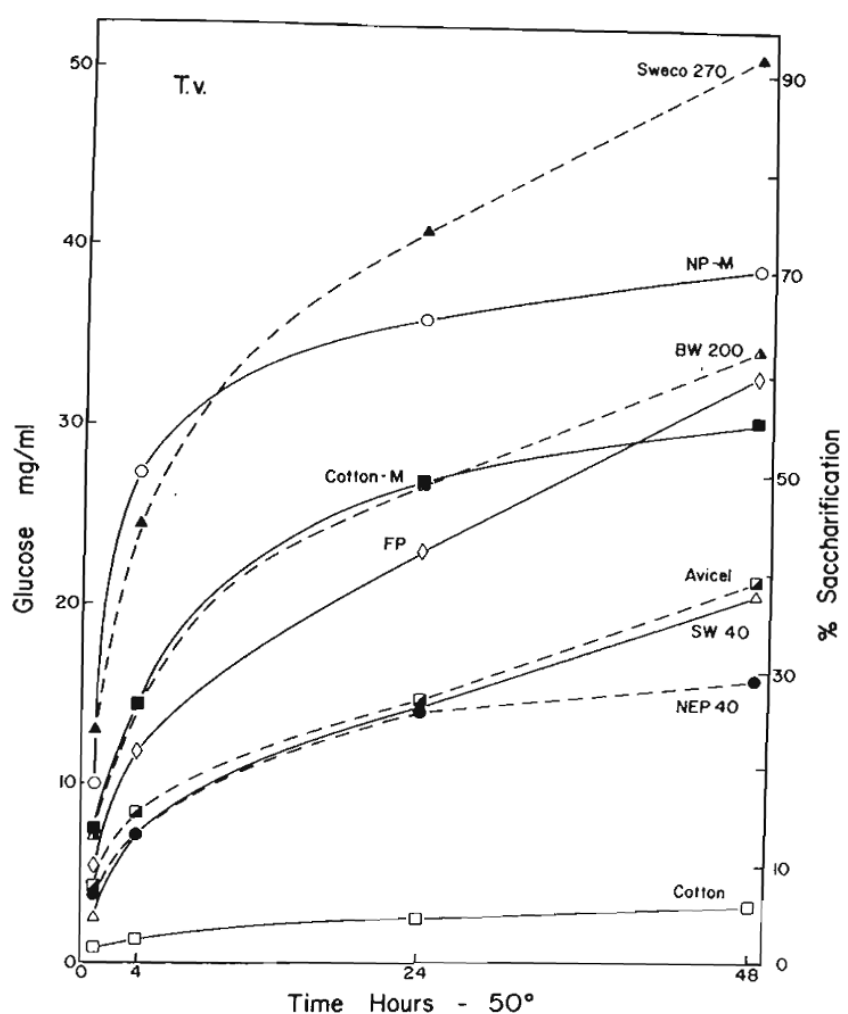

Figure I

Hydrolysis of insoluble cellulase by a complete cellulase from Trichoderma viride $5 \%$ cellulase incubated at $\mathrm{pH} 4.8,50^{\circ} \mathrm{C}$ with a filtrate of strain QM94I4 grown on cellulose medium. The enzyme preparation had $0.8 \mathrm{mg}$ protein, $25 \mathrm{C}_{\mathrm{x}}$ units, and 0.6 filter paper (FP) cellulose units/ml and a $C_{1}$ activity of $2.8 \mathrm{mg}$ of glucose/24 h. (white circle) Newspaper, Sweco ball milled; (black triangle) pure cellulose pulp, Sweco ball milled, 270 mesh; (white triangle) BW200, pure cellulose pulp, ball milled, Brown Co., Berlin, N.H.; (white diamond) Whatman No. I filter paper; (white square) ball milled absorbent cotton; (black square) Avicel pH 105, microcrystalline cellulose; $(\Delta-\Delta)$ pure cellulose pulp, SW4O. Brown Co.; (black circle) hammer milled newsprint, NEP40, Brown Co.; (white square) absorbent cotton, fibrous.

will hydrolyze it. So we had the choice of the most susceptible substrate or the most resistant, but both are unsatisfactory for a practical assay. Cellotetraose is not available commercially, but would have to be prepared by the investigator, a major research effort in its own right. Cotton is so slowly hydrolyzed that meaningful assays require $24 \mathrm{~h}$. Finally, neither cotton nor cellotetraose is representative of a realistic substrate.

In the early studies on cellulase the available enzyme preparations would scarcely hydrolyze insoluble cellulose although they often broke down soluble derivatives 
such as carboxymethyl cellulose (CMC) readily. This was because they consisted chiefly of endo $\beta$ glucanases $\left(C_{x}\right)$ and lacked the exo $\beta$ glucanases $\left(C_{1}\right)$. This is still true for cellulase preparations derived from organisms like Aspergillus niger or from plant extracts. For such cellulases carboxymethyl cellulose is used as a substrate (Table 2).

Since the action on CMC is only linear to about $12 \%$ conversion due to interference by substituents (Figure 2), the units per $\mathrm{ml}$ were defined as the inverse of the dilution to give 0.4 or $0.5 \mathrm{mg} / \mathrm{ml}$ of reducing sugar as glucose with $0.5 \%$ carboxymethyl cellulose as the substrate in first a $1 \mathrm{~h}$ and later a $30 \mathrm{~min}$ assay. These units were of course arbitrary, but they are quantitative and can readily and preferably be converted to standard units according to the International Union of Biochemistry (that is, 1 unit equals $1 \mu \mathrm{mol}$ of product per minute) (Table 2). A more serious deficiency is that the quantity of reducing sugars produced (and so the unit values) will be greatly affected by the particular sample of CMC used. The rate of hydrolysis is affected by both chain length and degree of substitution. Similar endo $\beta$ 1,4 glucanase assays can be developed for other cellulose derivatives such as cellulose sulfate, but the unit values will not be directly comparable. Since CMC is soluble, it is readily hydrolyzed. Trichoderma viride cultures will yield 50 to $150 \mathrm{CMC}$ units $/ \mathrm{ml}$ with a specific activity of about 100 units/mg of protein. Other organisms such as Pestalotiopsis westerdijkii may yield as much as $400 \mathrm{CMC}$ units/ml of culture filtrate.

For a practical measurement of saccharifying cellulase measurement of endo $\beta$ glucanase (or of any other single component) is unsatisfactory. For this reason the filter paper assay was introduced. It has the advantages of using a readily available and reproducible substrate that is neither too susceptible nor too resistant and that can be measured by unit area thus avoiding the tedium of weighing a solid or of trying to uniformly dispense a suspension of solids (Figure 3). The original filter paper (FP) activity referred to the amount of reducing sugar as

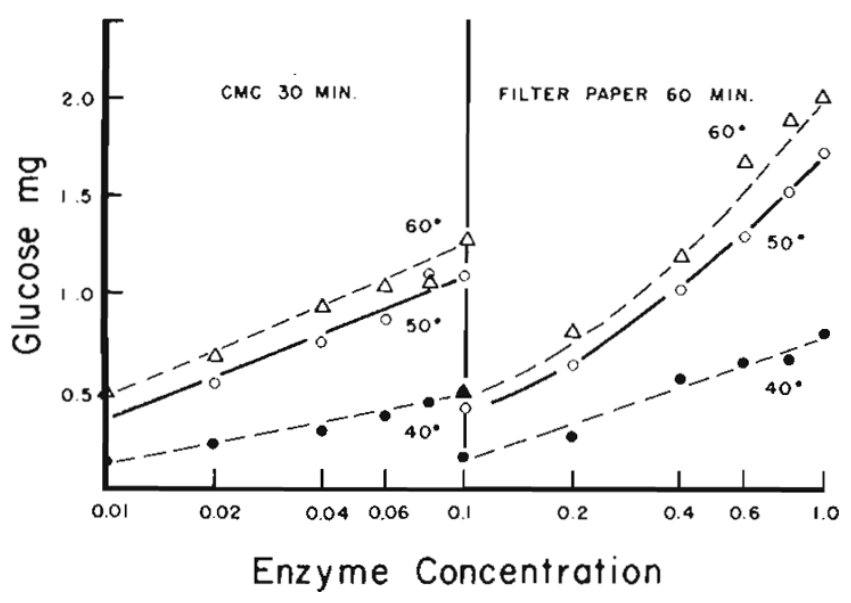

Figure 2

Effect of enzyme concentration and of temperature on hydrolysis of carboxymethyl cellulose and filter paper by Trichoderma viride cellulase. Culture filtrate of QM6a grown in cellulose, $12 C_{x}$ units, 0.2 filter paper units $/ \mathrm{ml}$. Filter paper activity $(1.0 \mathrm{ml}) \quad 1.74$. Black circle, $40^{\circ} \mathrm{C}$; white circle, $50^{\circ} \mathrm{C}$; white triangle, $60^{\circ} \mathrm{C}$.

glucose produced in the assay by $1 \mathrm{ml}$ of enzyme. This was acceptable for monitoring fermentations or for comparing enzyme production by different strains but it was not quantitative (Table 3, Figure 4). For more quantitative work we used a unit based on $0.5 \mathrm{mg}$ of glucose/ml analogous to the old $\mathrm{C}_{\mathrm{x}}$ unit [8].

Meantime in Peoria the assay was modified by increasing the cellulose to $100 \mathrm{mg}$ and reducing the incubation time to $30 \mathrm{~min}$ but calculating the results back to a 60 min activity value [10]. We also modified the assay to use only $0.5 \mathrm{ml}$ of enzyme $[11,12]$. At this point the literature and oral presentations were getting somewhat confused with the different assay procedures, loose references to FP activity as units, and calculating FP activities from shortened times or diluted enzyme preparations, giving apparently high but unreal values.

Table 2: Endo $\beta$ Glucanase $\left(C_{x}\right)$ Assay ${ }^{a}$

\begin{tabular}{llllllll}
\hline Reference & Enzyme, $\mathbf{m l}$ & $\mathbf{C M C}, \mathbf{m l}$ & $\mathbf{C M C}, \%$ in assay & Time, min & $\begin{array}{l}\mathbf{I} \mathbf{C}_{\mathbf{x}} \text { units/ml } \\
\text { Glucose } \mathbf{~ m g / m l} \mathbf{m l}\end{array}$ & $\begin{array}{l}\text { I } \mathbf{C}_{\mathbf{x}} \text { units/ml } \\
\text { Glucose total } \mathbf{m g}\end{array}$ & $\begin{array}{l}\text { International units } \\
\mathbf{C}_{\mathbf{x}} \text { units }\end{array}$ \\
\hline $\mathrm{A}^{\mathrm{b}}[6]$ & 1.0 & 9.0 & 0.5 & 60 & 0.4 & 4.0 & 0.37 \\
$\mathrm{~B}^{\mathrm{c}}[7]$ & 0.5 & 4.5 & 0.5 & 60 & 0.4 & 2.0 & 0.37 \\
$\mathrm{C}^{\mathrm{d}}[8]$ & 0.5 & 0.5 & 0.5 & 30 & 0.5 & 0.5 & 0.185 \\
\hline
\end{tabular}

${ }^{\text {a Substrate }}=$ carboxymethyl cellulose $(\mathrm{CMC})$, degree of substitution 0.5 . Temperature $=50 \mathrm{C}$. Product $=$ reducing sugar as glucose. Buffer $=0.05 \mathrm{M}$ citrate $\mathrm{pH} 4.8$. Calculations: I IU $=\mathrm{I} \mu \mathrm{mol}$ of glucose $/ \mathrm{min}(0.18 \mathrm{mg} / \mathrm{min})$. I mg glucose $/ 0.18 \times 60=0.0925$ units $(\mathrm{I} \mathrm{h})$ or I mg glucose $/ 0.18 \times 30=$ 0.185 units $(0.5 \mathrm{~h})$

${ }^{b} 4.0 \mathrm{mg}$ glucose $\times 0.0925 / \mathrm{l} .0 \mathrm{ml}$ enzyme $=0.37 \mathrm{IU} / \mathrm{C}_{\mathrm{x}}$ unit.

${ }^{c} 2.0 \mathrm{mg}$ glucose $\times 0.0925 / 0.5 \mathrm{ml}$ enzyme $=0.37 \mathrm{IU} / \mathrm{C}_{x}$ unit.

${ }^{\mathrm{d}} 0.5 \mathrm{mg}$ glucose $\times 0.185 / 0.5 \mathrm{ml}$ enzyme $=0.185 \mathrm{IU} / \mathrm{C}_{\mathrm{x}}$ unit. 


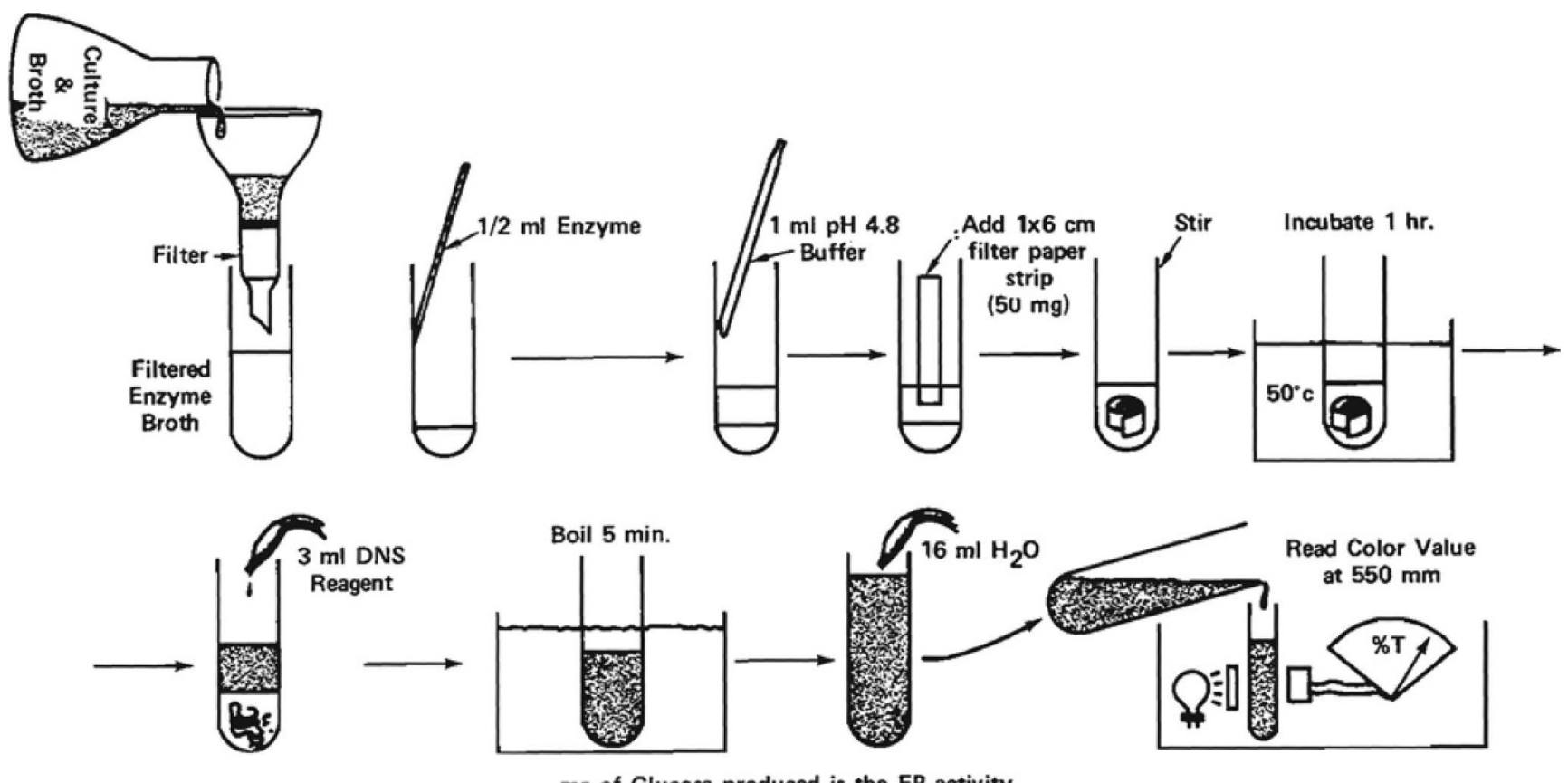

Figure 3

Filter paper assay procedure. Reagents: Whatman No. I filter paper cut into I $\times 6 \mathrm{~cm}$ strips $(50 \mathrm{mg})$; buffer $=0.05 \mathrm{M} \mathrm{Na}$ citrate $\mathrm{pH}$ 4.8; glucose standards in buffer; dinitrosalicyclic acid (DNS). Reagent for reducing sugar [9]. Filter or centrifuge culture sample to remove solids. Dissolve enzyme powders at 1.0 to $5.0 \mathrm{mg} / \mathrm{ml}$ in buffer. Dilute enzyme solutions in buffer. Place $0.5 \mathrm{ml}$ enzyme solution and $1.0 \mathrm{ml}$ buffer in $18 \mathrm{~mm}$ test tube. Add a filter paper strip and mix on Vortex mixer to coil the paper in the solution. Incubate $\mathrm{I} \mathrm{h}$ at $50^{\circ} \mathrm{C}$. Add $3 \mathrm{ml}$ DNS reagent to stop the reaction. Place tubes in boiling wate for $5 \mathrm{~min}$ and determine the amount reducing sugar as glucose. Include a blank tube (without filter paper) to correct for any reducing sugar present in enzyme preparation. The $\mathrm{mg}$ of glucose produced in this test is the filter paper (FP) activity. The DNS reagent [9] measures reducing sugar non-specifically. When glucose is used as standard, values for cellobiose will be about 15\% low and values for xylose about 15\% high on a weight basis.

Table 3: Filter Paper (FP) Activity and Units ${ }^{a}$

\begin{tabular}{|c|c|c|c|c|c|}
\hline \multirow[t]{2}{*}{ International units/ml } & \multirow{2}{*}{$\frac{\text { Filter }}{1.0 \mathrm{ml}}$} & \multirow{2}{*}{$\frac{\text { Paper }}{0.5 \mathrm{ml}}$} & \multicolumn{2}{|c|}{ Activity } & \multirow[t]{2}{*}{$\mathrm{ml}$ enzyme for $2.0 \mathrm{mg}$ glucose } \\
\hline & & & $0.2 \mathrm{ml}$ & $0.1 \mathrm{ml}$ & \\
\hline 0.05 & 0.54 & 0.27 & - & - & - \\
\hline 0.10 & 1.08 & 0.54 & - & - & - \\
\hline 0.20 & 2.10 & 1.08 & 0.40 & - & 0.925 \\
\hline 0.30 & 2.50 & 1.62 & 0.80 & - & 0.615 \\
\hline 0.40 & 2.80 & 2.10 & 1.10 & 0.40 & 0.463 \\
\hline 0.50 & 3.00 & 2.30 & 1.40 & 0.80 & 0.370 \\
\hline 0.75 & 3.90 & 2.80 & 1.75 & 1.10 & 0.248 \\
\hline 1.00 & 4.60 & 3.00 & 2.10 & 1.40 & 0.185 \\
\hline 1.50 & - & 3.90 & 2.65 & 1.75 & 0.124 \\
\hline 2.00 & - & 4.60 & 3.20 & 2.10 & 0.093 \\
\hline
\end{tabular}

a Substrate: $50 \mathrm{mg}$ Whatman No. I filter paper $\left(6 \mathrm{~cm}^{2}\right)$. Buffer: $1.0 \mathrm{ml}, 0.05 \mathrm{M}$ citrate $\mathrm{pH}$ 4.8. Enzyme: I ml assay, volume indicated + buffer to $1.0 \mathrm{ml} \mathrm{FP}$ activity $\times 0.0925=\mathrm{IU} / \mathrm{ml} ; 0.5 \mathrm{ml}$ assay volume indicated + buffer to $0.5 \mathrm{ml} \mathrm{FP}$ activity $\times 0.185 \mathrm{IU} / \mathrm{ml}$ or if FP activity is greater than $2.0 \mathrm{IU} / \mathrm{ml}=0.185 / \mathrm{ml}$ enzyme for $2.0 \mathrm{mg}$ glucose. $(2.0 \mathrm{mg}$ glucose $=4 \%$ hydrolysis of $50 \mathrm{mg}$; the unit based on $0.5 \mathrm{mg}$ of glucose from I ml of enzyme [8] is equal to $0.0463 \mathrm{IU}$.) 


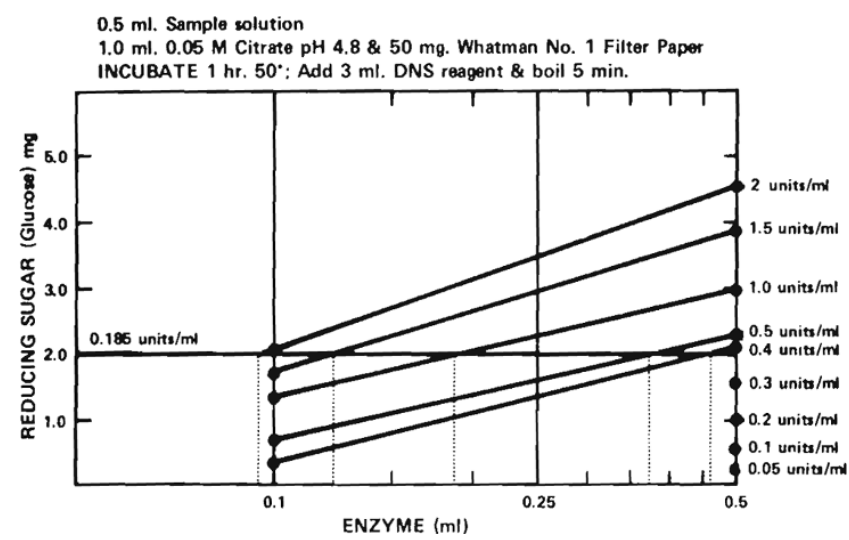

Figure 4

Measurement of filter paper cellulase units per $\mathbf{m l}$. Follow procedure as outlined in Figure 3. If filter paper (FP) activity for $0.5 \mathrm{ml}$ of enzyme is equal to or less than 2.0 , units per $\mathrm{ml}$ equal FP activity $\times 0.185$. If the FP activity is greater than 2.0, repeat using diluted enzyme and estimate the $\mathrm{ml}$ of enzyme required to give a FP activity of 2.0. Units per $\mathrm{ml}$ equals $0.185 / \mathrm{ml}$ of enzyme to give a FP activity of 2.0 .

A series of dilution curves (Figure 5) shows the effects of time, enzyme concentration, and cellulose concentration on the FP activity. It is evident that FP activity per unit of enzyme decreases with increasing enzyme concentration, that FP activity per unit of time decreases with increasing time of incubation, and that FP activity increases as cellulose concentration increases (Table 4).

It was obviously time to start using a cellulase unit based on the international unit system but two problems arose. The first problem was what concentration of cellulose to use in the assay and the second problem was what extent of conversion was required for meaningful results. For a soluble substrate the answers are simple. Substrate level should be high enough that it does not limit the reaction, and the extent of conversion should be slight before depletion of the substrate or product inhibition affects the reaction rate. Because of the low bulk density of cellulose, concentrations greater than about 5\% become very thick and since cellulose is insoluble, the effective concentration is the available surface. Increasing the effective cellulose concentration by adding more of it or by milling the cellulose will increase the rate of the reaction and also make it more linear to a higher sugar value [10] but this increases the relative contribution of the enzymes acting on the more amorphous portions of the cellulose. We are more interested in the hydrolysis of the more crystalline and resistant portions by the whole cellulase complex. Filter paper, like other insoluble celluloses is a multiple substrate ranging from free ends and amorphous regions to crystalline fibers.
When culture filtrates of $P$. westerdijkii (which contain only endo $\beta$ glucanases and $\beta$ glucosidase) and T. viride (which is a complete cellulase) are diluted to equal activity on carboxymethyl cellulose, the initial hydrolysis by both preparations is rapid (Figure 6). The Pestalotiopsis cellulase, however, levels off at less than $1.5 \%$ hydrolysis by $30 \mathrm{~min}$ and this does not increase on longer incubation. The Trichoderma cellulase continues to hydrolyze the more resistant portions although at a slower rate. Recently, Dr Elwyn Reese [13] has produced cellulase filtrates from Pestalotiopsis with over 200 international endo $\beta$ glucanase units per $\mathrm{ml}$ but they still have a FP activity of less than 0.8 . So a meaningful cellulase assay should show a greater percentage conversion than this.

Moving to a more resistant substrate makes for a more rigorous assay but even cotton contains a little amorphous cellulose. For example, Stutzenberger [14] reported that the cellulase of Thermomonospora curvata contained $\mathrm{C}_{1}$ based on reducing sugar production from cotton. The international unit values looked pretty good because the assay time was only $10 \mathrm{~min}$ but the sugar level did not increase even after $30 \mathrm{~h}$ incubation. So the action appears to be on a limited (less than 1\%) amorphous portion of the cotton. When we use cotton as a substrate, we incubate for $24 \mathrm{~h}$ and expect 5\% to $10 \%$ conversion by Trichoderma preparations. Another proposal by Naylor [15] was to run the filter paper hydrolysis for a longer time and use the slope of the hydrolysis curve after $16 \mathrm{~h}$. This is scientifically sound but time consuming and tedious if large numbers of assays are to be run.

Our solution to the problem has been to stay with the $50 \mathrm{mg}$ of filter paper and use $0.5 \mathrm{ml}$ of enzyme with $1 \mathrm{~h}$ incubation and to calculate international units as shown in Figures 3 and 4 from the dilution to give $2.0 \mathrm{mg}$ of glucose $(0.37$ units $/ \mathrm{ml}$ if the $0.5 \mathrm{ml}$ assay is used). This cut-off value of 2.0 was chosen because the hydrolysis curves are fairly linear to beyond that level and because it represents $4 \%$ hydrolysis of the filter paper, well over the amount of sugar that could be expected from an incomplete cellulase. Higher unit values would result if the cutoff value were lower, if the assay time were decreased, or the cellulose concentration were increased.

Trichoderma cellulase fermentations as we are running them at Natick with the mutant strain QM9414 yield 1 to 2 units of cellulase/ml of culture broth for a specific activity of about $1 \mathrm{unit} / \mathrm{mg}$ of protein as determined by this assay. The amount of saccharification to be expected from such enzyme levels is shown (Figure 7) for pure milled cellulose. 

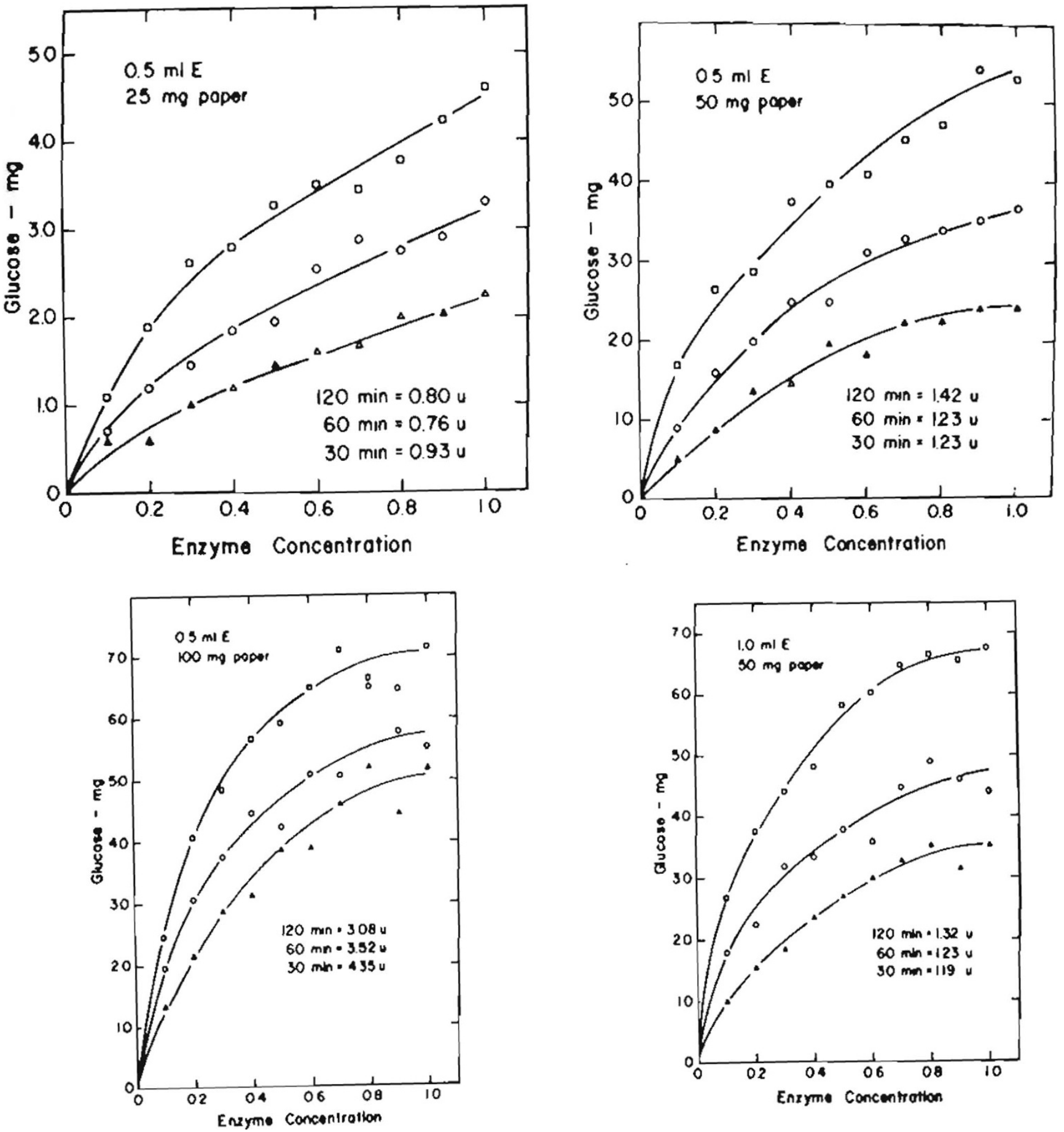

Figure 5

Hydrolysis of filter paper by Trichoderma viride cellulase. Effect of assay conditions, 0.5 or I.0 ml enzyme $+\mathrm{I} \mathrm{ml}$ buffer $\mathrm{pH} 4.8+25,50$, or $100 \mathrm{mg}$ Whatman No. filter paper. Units $=\mu \mathrm{mol}$ of glucose $/ \mathrm{min}$ based on dilution to give $2 \mathrm{mg}$ of glucose. White triangle, $30 \mathrm{~min}$ incubation $50^{\circ} \mathrm{C}$; white circle, $60 \mathrm{~min}$ incubation $50^{\circ} \mathrm{C}$; white square, 120 min incubation $50^{\circ} \mathrm{C}$. 
Table 4: Effect of Conditions on Filter Paper Assay ${ }^{a}$

\begin{tabular}{|c|c|c|c|c|c|}
\hline $\begin{array}{l}\text { Filer paper } \mathrm{mg} \\
\text { Enzyme } \mathrm{ml} \\
\text { Enzyme protein } \mathrm{mg}\end{array}$ & & $\begin{array}{l}25 \\
0.5 \\
0.7\end{array}$ & $\begin{array}{l}50 \\
0.5 \\
0.7\end{array}$ & $\begin{array}{l}50 \\
1.0 \\
1.4\end{array}$ & $\begin{array}{l}100 \\
0.5 \\
0.7\end{array}$ \\
\hline Activity mg glucose & $\begin{array}{l}30 \mathrm{~min} \\
60 \mathrm{~min} \\
120 \mathrm{~min}\end{array}$ & $\begin{array}{l}2.29 \\
3.30 \\
4.60\end{array}$ & $\begin{array}{l}2.43 \\
3.68 \\
5.30\end{array}$ & $\begin{array}{l}3.52 \\
4.40 \\
6.75\end{array}$ & $\begin{array}{l}5.18 \\
5.53 \\
7.16\end{array}$ \\
\hline Activity per $\mathrm{h}$ & $\begin{array}{l}30 \mathrm{~min} \\
60 \mathrm{~min} \\
120 \mathrm{~min}\end{array}$ & $\begin{array}{l}4.58 \\
3.30 \\
2.30\end{array}$ & $\begin{array}{l}4.86 \\
3.68 \\
2.65\end{array}$ & $\begin{array}{l}7.04 \\
4.40 \\
3.38\end{array}$ & $\begin{array}{l}10.36 \\
5.53 \\
3.58\end{array}$ \\
\hline Units/ml & $\begin{array}{l}30 \mathrm{~min} \\
60 \mathrm{~min} \\
120 \mathrm{~min}\end{array}$ & $\begin{array}{l}0.93 \\
0.76 \\
0.80\end{array}$ & $\begin{array}{l}1.23 \\
1.23 \\
1.42\end{array}$ & $\begin{array}{l}1.19 \\
1.23 \\
1.32\end{array}$ & $\begin{array}{l}4.35 \\
3.52 \\
3.08\end{array}$ \\
\hline Units/mg protein & $\begin{array}{l}30 \mathrm{~min} \\
60 \mathrm{~min} \\
120 \mathrm{~min}\end{array}$ & $\begin{array}{l}0.66 \\
0.54 \\
0.57\end{array}$ & $\begin{array}{l}0.88 \\
0.88 \\
1.01\end{array}$ & $\begin{array}{l}0.85 \\
0.88 \\
0.94\end{array}$ & $\begin{array}{l}3.11 \\
2.51 \\
2.61\end{array}$ \\
\hline
\end{tabular}

${ }^{\mathrm{a}} 0.5$ or $1.0 \mathrm{ml}$ of enzyme (culture filtrate of QM94I4 grown on cellulose) + I ml of pH 4.8 buffer + Strip of Whatman No. I filter paper. Units $=\mu \mathrm{mol}$ of glucose per min based on the dilution to give $2.0 \mathrm{mg}$ glucose.

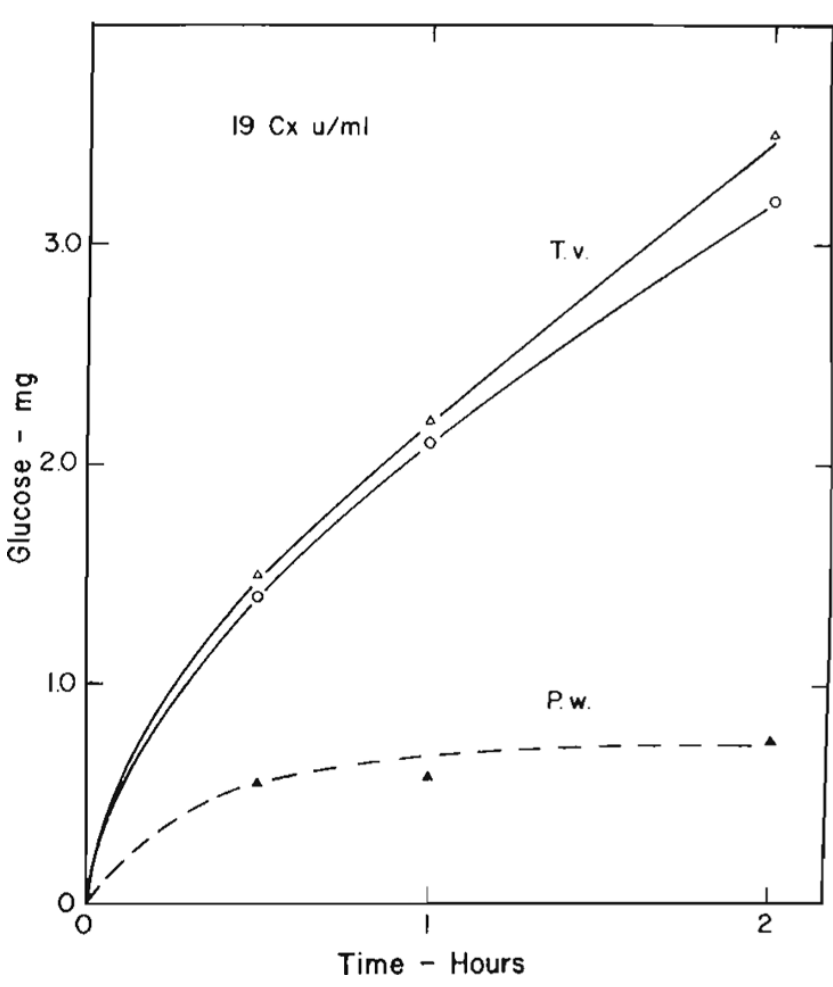

Figure 6

Hydrolysis of filter paper by cellulase preparations from Trichoderma viride and Pestalotiopsis westerdijkii adjusted to equal activities on carboxymethyl

cellulose. Culture filtrates diluted to $19 \mathrm{C}_{\mathrm{x}}$ units per $\mathrm{ml}$. $0.5 \mathrm{ml}$ enzyme $+\mathrm{I} \mathrm{ml} \mathrm{pH} 4.8$ buffer $+50 \mathrm{mg}$ paper. Incubated at $50^{\circ} \mathrm{C}$. White triangle, $\mathrm{T}_{\mathrm{v}} \mathrm{QM} 9 \mathrm{I} 23$ culture filtrate; white circle, $T_{v}$ QM94I 4 culture filtrate; black triangle, $P_{w}$ QM38I culture filtrate.
In conclusion, the measurement of cellulase is complex and there is no absolute unit as can be measured for a single enzyme acting on a soluble substrate. The unit value will depend on the substrate chosen, its concentration, and the extent of conversion. The filter paper assay and unit value described here is not perfect but it is simple, reproducible, and quantitative and predicts enzyme action under practical saccharification conditions.

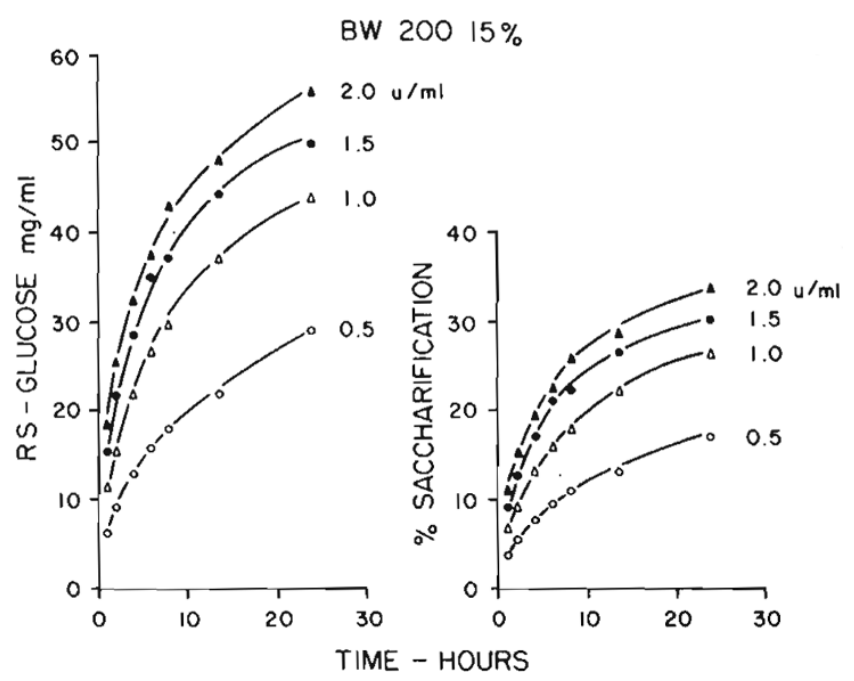

Figure 7

Hydrolysis of milled cellulose pulp by Trichoderma viride cellulase. I liter stirred tank reactor at $50^{\circ} \mathrm{C}$, with $15 \%$ ball milled cellulose (BW200, Brown Co., Berlin, NH, USA), cellulase culture filtrate from QM94I4, in $0.05 \mathrm{M}$ citrate buffer. Percentage saccharification equals glucose $\mathrm{mg} / \mathrm{ml} \times 0.6$. 


\section{Acknowledgements}

This article originally appeared in Biotechnol Bioeng Symp 1976, 6:21-33.

Republished with permission of John Wiley \& Sons, Inc.

\section{References}

I. Toyama N: Enzymatic Hydrolysis of Cellulose and Related Materials Pergamon Press, New York: Reese ET 1963, 235.

2. Linko M: SITRA Symposium on Enzymatic Hydrolysis of Cellulose, Aulanko, Finland Bailey M, Enari TM, Linko M 1975, 297.

3. Cowling E: Cellulose as a Chemical and Energy Source. (Biotechnol Bioeng Symp, No. 5) Wiley-Interscience, New York: Wilke CR 1975, 163.

4. Petterson LG: SITRA Symposium on Enzymatic Hydrolysis of Cellulose, Aulanko, Finland Bailey M, Enari TM, Linko M 1975, 295.

5. Halliwell G: SITRA Symposium on Enzymatic Hydrolysis of Cellulose, Aulanko, Finland Bailey M, Enari TM, Linko M 1975, 319.

6. Reese ET, Siu RGH and Levinson HS: J Bacteriol 1950, 59:485.

7. Mandels M and Reese ET: J Bacteriol 1957, 73:269.

8. Mandels M and Weber J: Advan Chem Ser 1969, 95:391.

9. Miller GL: Analyt Chem 1959, 3 I:426.

10. Griffin HL: Analyt Biochem 1973, 56:621.

II. Mandels M, Hontz L and Nystrom J: Biotechnol Bioeng 1974, I 6: |47 I.

12. Mandels M: Cellulose as a Chemical and Energy Source. (Biotechnol Bioeng Symp, No. 5) Wiley-Interscience, New York: Wilke CR 1975, 8I.

13. Reese ET: personal communication 1975 .

14. Stutzenberger F: Appl Microbiol 1972, 24:77.

15. Naylor J: personal communication 1974

Publish with BioMed Central and every scientist can read your work free of charge

"BioMed Central will be the most significant development for disseminating the results of biomedical research in our lifetime. "

Sir Paul Nurse, Cancer Research UK

Your research papers will be:

- available free of charge to the entire biomedical community

- peer reviewed and published immediately upon acceptance

- cited in PubMed and archived on PubMed Central

- yours - you keep the copyright

Submit your manuscript here:

http://www.biomedcentral.com/info/publishing_adv.asp
BioMedcentral 